\title{
Literature Review: Communication Infrastructure and Wireless Communication in Estonia
}

\author{
Kimberley Leahy \\ Florida State University, Tallahassee, FL, USA \\ kimberley leahy@yahoo.com
}

\begin{abstract}
Telecommunications is one of the fastest growing markets in Estonia. Of the three Baltic States, research has shown that Estonia, while the smallest, has made by far the most successful foray into the wireless communication arena. Economic and public policy within the former Soviet Union had left Balkan communication infrastructure in disarray, and liberalization of the Estonian telecom sector was necessary for the country's bid for EU membership. This paper will discuss the literature addressing Estonia's leap into twenty-first century communication technology, with its savvy bypass of obsolete communication infrastructure paradigms inherited from the former Soviet Union.
\end{abstract}

Keywords : Estonia, Wireless Communication, Communication Infrastructure, Communication Technology

\section{Introduction}

With Soviet Rule a decade in the past, Estonia finds itself positioned to accept welcome into a Community which a dozen years ago existed only as an idea, and into an Organization from which their annexation by the Soviet Union had kept them barred. As Estonians begin to forge new ties with their European neighbors, as well as new alliances with former Cold War era foes, a myriad of social, economic and political considerations await them. Managing new interactions while bringing their economy into a new millennium will require facile administration of, among other elements necessary for a successful transition, communication technologies.

Shenk (1996) tells us that Soviet policy governing information transmission had left Estonia's communication infrastructure in disarray. Yet, as Dyer-Witheford (1999) shares, only a decade after Soviet occupation finally ended in the Baltic region, the latest communication technologies have allowed Estonia to leapfrog into a new and modern economic paradigm. While the leap has been largely successful, Estonia's emergence from Soviet control has presented challenges previously unknown within their staterun market cooperatives. Kruse (1999) points out that one of these challenges has been how to maximize an antiquated telecommunication infrastructure using scarce resources spread across disparate industries each in desperate need of modernization. The question Estonia faced was whether to invest in patches to existing communication systems, built upon a decaying legacy system of hard-wired telecommunications - a very expensive proposition - (Hulten \& Mollery, 1997) or to re-engineer the coun-

Material published as part of these proceedings, either on-line or in print, is copyrighted by Informing Science. Permission to make digital or paper copy of part or all of these works for personal or classroom use is granted without fee provided that the copies are not made or distributed for profit or commercial advantage AND that copies 1) bear this notice in full and 2) give the full citation on the first page. It is permissible to abstract these works so long as credit is given. To copy in all other cases or to republish or to post on a server or to redistribute to lists requires specific permission from the publisher at Publisher@InformingScience.org try's communication infrastructure using state-ofthe-art wireless technology, a decision which would have far-reaching impact on business, consumers and policy-makers (Radosevic, 1997).

In the spirit of shrugging off all that represented Soviet domination, Estonia, as well as many other Central and Eastern European Countries, embraced wireless technology as the de facto choice 
for paving the way into the next thousand years of communication. While perhaps cloaked in nationalism, Bruce (1999) sees the decision to eschew Soviet fixed line telecommunications in favor of wireless connectivity to have placed Estonia in excellent stead both technologically and economically as the region begins its foray into liberalization and market competition. Given that Estonia wishes to present a compelling case for inclusion in the European Union (EU), advantaging all the good that comes from membership in an organized economic and political collective, Clemens (2001) favors the Estonian decision to represent itself as free from any ties to the totalitarian regime which once exerted complete control over an artificially supported market. The decision illustrates the level of commitment that Estonia has to the future of Europe and their role in it. The choice of a primarily wireless communications base is just one component of Estonia's push toward modernization and economic inclusion, yet it is significant as it represents not only a breaking from the past, but an understanding of the requirements for future economic participation with the European Union (UNDP, 2002).

This paper will address the key issues of research to date surrounding wireless communication with respect to Estonia. It will evaluate the meaning of infrastructure and how that meaning can be applied within the context of Estonia's decision to move toward a wireless communication platform, assess the literature discussing the lead up to Estonia's decision to cut the wires to the Soviet Union, and present a critical overview of industry research addressing wireless offerings deployed in Estonia, specifically addressing various authors' opinions on the implications of wireless technology in Estonia and the infrastructural considerations this new technology will bring to bear as it becomes more prevalent . This paper will attempt to answer the questions, "What do researchers feel are the infrastructural considerations surrounding Estonia's decision to move to a wireless platform," "How does contemporary literature treat Estonia's decision to focus on wireless technology as a communication platform," and "What do the authorities in the field feel are the challenges of wireless communications infrastructure in Estonia?"

The reasons for these questions center around the economic considerations of jettisoning an existing infrastructure in favor of state-of-the art technology and the implications this decision has not only on the communications industry in Estonia, but on the vast number of industries communications touches and impacts. Wireless technology is held out as the new gold standard for communications, differentiating this millennium from the last. This paper will offer a comparison among the literature that speaks to wireless telecommunications technology, as well as provide an overview of the research surrounding telecommunication infrastructural change specific to Estonia. These topics are important as Estonia attempts to balance not only national interests against EU inclusion - their choice for telecommunication representing but one of the numerous factors weighed in the EU committee requirements - but most important as the country attempts to layout a framework for telecommunications taking into account today's needs, budgetary considerations, and decisions for long term telecommunications infrastructural planning.

\section{Telecommunications Infrastructure Defined}

We begin with background on telecommunications infrastructure to provide a definition for the basis of discussion. Star and Bowker (2002) reference Star and Ruhleder (1996) when describing the salient points of infrastructure: that is, that infrastructure is embedded within other structures and technologies; it is transparent in use, not needing to be reinvented at each use and only becoming evident when it breaks down; that infrastructure can be specific or general in scope; it is a natural component of usage to its initiates but must be learned by outsiders; it links with the past in practices of convention and is modified for future expansion, building upon the strengths and weaknesses of the installed base such that infrastructural changes are limited or enhanced by systems already in place. This background of infrastructure is important as we consider the issues with which Estonia wrestled concerning infrastructural change in its telecommunication systems. The decision to select a new technology over a current technology with existing infrastructure already in place has resonance beyond the initial decision. Star 
and Bowker cite numerous authors when describing how choices in infrastructure are usually predicated upon choices made in the past, choices which have been indeliblely folded into the application of new technology (Star \& Bowker, 2002).

With respect to infrastructural application, Hughes referenced reverse salients, or that which slows the development of a new infrastructure not specific to the infrastructure itself, i.e. a technological challenge stemming from a political challenge. He contends that the solution to the initial problem, that being one of politics, for example, need not focus on politics at all but can address itself directly to the technology in question (Hughes, 1983). This assertion becomes important to a country like Estonia, which finds itself struggling with old paradigms of controlled telecommunications markets yet wishes to move to a liberalized market with a new communication infrastructure, wireless technology, as its springboard.

Bowker's concept of infrastructural inversion is important to mention here. In his analysis, Bowker (1996) shows us that although remarkable societal change may appear to come from the product of an age, for example in Estonia's case the wireless cell phone, it is really the infrastructural change, or the technology serving as the underpinnings for the product, which lead to the change which society experiences. The concept of network externalities amplifies this point. Star and Bowker refer to works by David, Greenstein, and Rothwell (Star \& Bowker, 2002) illustrating how, as technology is adopted by more and more people, the value of that technology for those who already employ it increases even as its value increases for the late adopters. A simple example used by the authors is that of the telephone. With telephone technology, a network developed which was important to those who adopted its use, and, as more individuals came to adopt the technology, the technology became increasingly more powerful for all its users. That power led to even greater adoption of the technology, and so on, with this exponential growth resulting in powerful network externalities.

The concept of network externalities of wireless communication has had significant impact in Estonia, specifically in the form of Short Messaging Service (SMS). If, for example, only one person were to own a cell phone with SMS, its capabilities could not make nearly the societal impact that a network of consumers with the technology has made, nor would entire industries spring from only a single consumer's use of SMS. In Estonia, the network externalities of SMS can be found at levels of the economy as esoteric as the capital city Tallinn's parking authority. When mobile subscribers need to leave automobiles parked for a time, they enter a number into their cell phone, which, as part of a subscription offered, is tied to the city's parking service. The number, based on the subscriber's cell phone number and auto license number, is entered into Tallinn's parking service database, along with where the car is parked and beginning at what time. The parking rate is tied to the location. When a meter monitor checks on the subscriber's parking status, she or he would see a mobile parking sticker on the subscriber's windshield. An SMS entry to the parking database by the meter monitor confirms that the subscriber does in fact have a mobile parking license and did register to park; a ticket would be issued otherwise. Subscribers must remember to notify the system with another SMS when they have vacated the parking space, or else the database will continue to charge the subscriber for parking for up to four hours beyond the required time for payment. Tallinn has contracted with Estonia Mobile Telephone, Inc. to manage the parking database and to bill the customers, receiving a portion of the revenues for its services, as a credit-card processor would. The parking database and SMS service, started in July 2000, in July of 2001 had about 12,000 registered users who either have their wireless provider bill them directly for parking, or who pre-pay for their wireless phone use and apply some of their minutes toward parking (Dyson, 2001).

This example is only one of many highlighting Estonia's leap to embrace wireless technology. Government reports, NGO case studies, industry analysis, and journalistic inquiry have all documented Estonia's rapid acceptance of wireless communications into the infrastructure of society. Still, with the newness of the technology, Estonia grapples with the ever-expanding potential of wireless communications and how to standardize the technology to best meet the needs of Estonia's consumers. Star and 
Bowker explain the continuum of strategies for setting standards with respect to telecommunication infrastructure, moving from the idea that one standard fits all - a deterministic approach (Lievrouw, 2002) - to a concept, as the authors term it, of "let a thousand standards bloom," (Star \& Bowker, 2002), calling the first a colonialistic approach and the other a democratic approach. How appropriate then that Estonia struggles with these very infrastructural issues as it seeks to identify itself with a European democratic social model rather than the deterministic Soviet society.

\section{The Move Toward a Market Driven Economy}

There has been extensive study conducted on the debut of former Soviet Block nations into a globalized, competitive economy. One area of particular study has been of social change in the wake of Socialism. Lievrouw and Livingstone (2002) characterize social change as shifts in cultural behavior around which is framed a new collective interaction. Social change marked post-Soviet Eastern Europe with a shift in ways of interacting within a new economy and political framework. Where prior to 1991 the State controlled all sources of production, almost overnight Entrepreneurialism had become the rallying cry. Literature investigating this phenomenon of market driven economies in formerly Soviet states addresses the emergence of the individual as a determinant of demand (Eremicheva \& Solovieva, 1997), the new phenomenon of class in a formerly classless society (Slomczynski, 1997), how the young responded to changing professional expectations within an ever changing social landscape (Semenova, 1997), and how a changing society deals with those who succeed, and, perhaps more importantly, those who lose, when a patriarchal culture cedes its authority to an economy far less pluralistic (Taljunaite \& Cesnaviscious, 1997). Each of these perspectives shows us, from various points in the prism, just how complicated managing social change can be, especially, as many of our authors point out, when the expectation set concerning capitalism is very different depending on where an individual falls along the selfsufficiency continuum.

Although Estonia, along with the other breakaway nations, initiated their separation from the Soviet Union, studies such as the one conducted by Braliev and Kalvet (2002) remind us that the private sector still plays a role in how their economies are managed. The State in many Baltic countries still retains oversight of telecommunication operations, along with many other facets of the economy. Aage (1997), writes how the giving over of control of primary governmental functions critical to national interests to profit motivated public sector is a leap of trust that few formerly Soviet block nations have been willing to make. In support of this point Pelikan (1997) argues that it is a leap that these countries must take or face repeating the economic scenario felt under Soviet management: creeping infrastructural obsolescence. Further, Gylfason (1997) tells us is that what these countries will come to discover - or not, at their own peril - is that positive externalities of the not necessarily wholesome system of capitalism include process efficiency and economic growth. Nevertheless, just like any move toward democratization, the process is, in the words of Thomas Jefferson, evolutionary, not revolutionary. Intrigalator (1997) seconds this perspective, pointing out that there remains a place for the State to manage change and provide continuity as emerging democracies prepare for take off, ensuring that too much growth does not occur too fast. Eliasson (1997) takes the perspective a step further, outlining how the State can provide incentive for investment while gradually easing its grip on the controls to ensure a seamless transition toward liberalized service offerings.

\section{Estonia's Wireless Communication}

Of the three Baltic States, research has shown that Estonia, while the smallest, has made by far the most successful foray into wireless communication. The U.S. Department of Commerce in 2002 released a report noting the key developments that have taken place in Estonia in terms of telecommunication infrastructure, leading Estonia to become the most advanced of the Central and Eastern European Countries (USDOC, 2002). One of those advancements includes the country's having liberalized, or opened 
to competition, their fixed line communication infrastructure. Local loop unbundling (LLU), allowing competitors to access the 'last mile' of copper network leading to the end customer, is an issue relevant to those EU prospective member countries such as Estonia who are in more advanced stages of liberalization, and constitutes a key area in which progress will have to be made before countries find the mselves in accordance with the EU telecommunication market requirements (Baltic News Service, 2002). Leppik (2002) points out that not only has the Estonian telecommunication market adopted completely open competition since January 1, 2001, it is still the only one of the Baltic States to fully do so. Fjallborg (2000) reminds us that this is important because the liberalization of the Estonian fixed line telecommunication sector is a major component in the country's bid for EU membership.

Perhaps because of its newness, Estonia's mobile sector, unlike their fixed line market Bitzer \& von Hirshenhauser point out (2001), was never state-regulated. According a recent Estonia Regulatory Master Report (2000) by the end of the first quarter of 2000, the country's three mobile operators had 724,000 mobile users/customers, with a fourth provider projected to gain licensing by the end of 2002 to service pent up demand. The World Bank (2001) places Estonia among the fastest growing telecommunications sectors in Europe, with wireless communications as the driving force behind that growth. Reports from the International Telecommunications Union show that in Estonia, as in neighboring Finland, the number of mobile subscribers has surpassed the number of fixed lines per capita, and that there are 40 mobile connections, compared to 36 fixed lines, per 100 Estonians (ITU, 2002). According to a study conducted by Accenture Consulting (2001), "the Estonian telecommunication market is presently insatiable and searching for new possibilities (for) new solutions and products." The study goes on to say that, "at present the Estonian telecommunication market is in an extraordinary situation where the proportion of ... mobile phones is surprisingly high: states with much higher GDP are placed in the list behind of Estonia." While no recent literature was found to dispute Estonia's rapid adoption of wireless technology, authorities do take issue with the wireless protocols available and which among them is the most suitable platform upon which to build Estonia's wireless future.

\section{The Standardization Debate}

Luna (2000) quotes the Gartner Group when she writes that the Estonian mobile network is fully compatible with the Global System for Mobile Communication (GSM), has a network coverage area of 98 per cent of the territory, reaching 99 per cent of the population. Estonia has also, according to Ericsson Corporation (2002) embraced the Wireless Application Protocol (WAP), the wireless protocol most widely used throughout the European Union and important for bearer and device independence and interoperability. A brief background description of wireless protocols, a summary of Kathleen Carr's extensive industry report, will facilitate explanation as to challenges in the wireless community concerning infrastructural standardization:

First and Second Generation Personal Communication Systems (PCS) networks are characterized by the existence of a large number of networks, each specific to its own geographical region. PCS subscribers can maintain wireless service as long as they stay within the coverage area of the home service provider. When the subscriber travels to another region, service is available only if an advanced roaming agreement has been made between the home and the visiting service providers. As well, $2 \mathrm{G}$ and $2.5 \mathrm{G}$ technology deliver data at only 20-30 kbps, preventing optimal transmission of complex data applications. In contrast, in the next generation, $3 \mathrm{G}$, wireless networks will employ a multi-tier architecture networks from that will provide coverage to subscribers with varying mobility and calling characteristics. The tiers will offer tight integration for improved service coverage and seamless communication, irrespective of subscriber location or mobility pattern. Further, $3 \mathrm{G}$ wireless offers connectivity at up to $2 \mathrm{Mbps}$, a speed unreachable with today's technology (Carr, 2002).

Estonian mobile operators were among the first in the world to introduce (WAP) services to their customers, and Estonia's Transportation and Communication Ministry expects to issue 3G UMTS 
licenses in the early part of 2003. Although full leveraging of 3G's emerging technology will not come for some years yet, Estonia's Universal Mobile Telecommunication System licenses position the country well for capitalizing on market demand as soon as technologically feasible. The participation fee is set at approximately US\$3 million(World Markets Telecom, 2001).

The difficulty that Columbia University brought out in a recent study is whether, with respect to these elevated wireless protocols, there is a market for this wireless technology, and, by the time demand for these services catches up with service offerings, will the technology have changed such that many disparate protocols will have become obsolete. Even more importantly, Columbia goes on to ask, will there exist a standardized global infrastructure to support the applications, much as there is with wired telephony and the World Wide Web (Citi, 2001). Star and Bowker state clearly that standards are necessary. Yet they acknowledge that the difficulty with developing information infrastructure is that any commitment to a standard requires a relatively stable technology and communication with respect to the chosen direction for development (Star \& Bowker, 2002). In contrast, wireless is still a moving target, with 4G technology on the horizon. Further, there exists an aspect to wireless communication which, as it cannot yet even be regulated, stands very little chance of having standards applied to it.

Cornwell (2002) writes about one of the unregulated wireless technologies creating a buzz among industry insiders - WiFi (Wireless Fidelity, WLAN, wireless local area network). He shares that this IEEE 802.11b specification allows for the wireless transmission of approximately $11 \mathrm{Mbps}$ of raw data at indoor distances from several dozen to several hundred feet, and outdoor distances of several to tens of miles as an unlicensed use of the $2.4 \mathrm{GHz}$ band. Negroponte (2002) writes of cafes in Estonia cropping up where Wifi-ers can link to one another, or to unsuspecting wireless LAN subscribers, for free. Needless to say, any technology that is so unregulated is bound to have its detractors. The Boston Globe offers a balanced article highlighting Wifi, with an inclusion of the perspective that Wifi use is akin to stealing from those who pay for the wireless LAN's into which Wifi taps. Proponents of Wifi such as Biddlecomb (2002) make the typical claim that the technology hurts no one and makes communication possible for may more users than land based LAN's. She tells of Estonian Wifi enthusiasts tapping in to wireless LAN's at gas stations and even Tallinn Airport. The technology is so new that even a state formerly accustomed to controlling every aspect of communication dissemination, has yet to come to grips with how to regulate Wifi without stepping on the new-found freedoms of information exchange.

Numerous authors agree that standards and regulation can be applied to wireless communications, but few so far have offered solutions on what standards and regulations would be appropriate or how they should be applied. Open Mobile Alliance, a consortium of over 200 firms with ties to the wireless industry, tells consumers that its mission statement is "collect market requirements and define specifications designed to remove barriers to interoperability and accelerate the development and adoption of new, enhanced mobile information, communications and entertainment services and applications," (2002). Analysts close to the wireless industry confirm that this type of organization is long overdue, and expand the ir critique to include a need for standards and regulations concerning most ancillary businesses that touch the wireless industry. Sutherland (2002) questions whether this new consortium can pull together the disparate technologies that comprise wireless communications. He quotes Vodaphone's CEO as saying that the fragmented wireless industry has created a negative experience for mobile users, and goes on to say that the far flung wireless communication industry should focus on adopting technology standardizations to improve ensure that infrastructure surrounding wireless technology ultimately finds itself on a single track. No studies could be found which would refute this line of thinking. Most industry experts look forward to the day when all things wireless conform to a single standard, much in the way Beta ultimately ceded dominance to VHS. The current wireless situation harkens back to earlier discussions in this paper citing the Star and Bowker comparison of colonialistic versus democratic telecommunication standardization approaches. Their research is appropriately applied to the question of where along the continuum standards for wireless communication and its infra- 
structure should fall. While most researchers would not want to resort to the deterministic approach Lievrouw discusses concerning technology's deployment, neither do they wish to continue in an unstructured environment with little direction or focus.

\section{Conclusions}

Concerning wireless technology and its infrastructure, we still exist in the land where "a thousand technologies bloom". Nearly all of the literature surrounding wireless connectivity states that we need more uniformity, but no authors could be found who would address how to go about setting industry standards. We have seen how Estonia has moved from a place of complete communication control to one where, with respect to a very new technology, few standards or controls exist. Researchers have provided us with a definition of infrastructure and why it is important, which was then underscored by a discussion of the lack of uniform infrastructure in wireless communication. We acknowledged that some standardization is endorsed by industry experts and, though we may not yet know how that standardization will manifest, we know that we wish not to revert to a state-controlled telecommunications system such that was prevalent in the deterministic Soviet era.

Authors in the field of emerging democracies have shown that nations, with adequate preparation and flexibility, can encourage entrepreneurialism where once all market decisions were made by the state. For Estonia, the wireless decision was seen as one component of leaving behind the communication infrastructure of the Soviet era and joining the European Union. As it did so, we saw that the country, sole among its Baltic neighbors, embraced the market liberalization of telecommunication services, further illustrating to the European Community their commitment to free and open markets. Although experts agree that wireless communications still need structure and standards, Estonia is seen to have successfully implemented wireless communications opportunities putting itself well in position to compete on the global market.

\section{References}

Aage, H. (1997). Public sector development: Difficulties and restrictions. In Haavisto, T. The Transition to a Market Economy: Transformation and Reform in the Baltic States. Cheltenham, UK; Brookfield, Vt., US: Elgar.

Accenture Consulting .(2001). Creating a development dynamic, Final report of the digital opportunity initiative. Appendix 3.3, Estonia Case Study. Researched for United Nations Development Programme in cooperation with the Markle Foundation.

Biddlecomb, E. (2002 March 26). Estonians pump Wifi with petrol. The Inquirer. Retrieved November 5, 2002 www.theinquirer.net

Bitzer, J. \& von Hirshenhauser, C. (2001). Rebuilding infrastructure in the Balkan countries: The stony way from socialism to capitalism. University of Glasgow, Glasgow Scotland.

Braliev, A. \& Kalvet, T. (2001). Dot EE. Harvard University Center for International Development.

Bruce, R. (1999). Overcoming obstacles to liberalization of the telecom sector in Estonia, Poland, the Czech Republic, Slovenia, and Hungary: an overview of key policy concerns and potential initiatives to facilitate the transition process. Washington, D.C.: World Bank.

Carr, K. (2002 March). 3G or not 3G, that is the question. Darwin. Retrieved November 5, 2002 http://www.darwinmag.com/read/030102/3g.html

Citi. (2001). Key drivers for 3G wireless: Will it deliver or is it just hype. (Tech Paper) Columbia University.

Clemens, W. (2001). The Baltic transformed: Complexity theory and European security. Lanham, Md.; Oxford: Rowman \& Littlefield.

Cornwell, S. (2002 September 19). Roaming between Wifi and 3G networks achieved. Newsworld.

Dyer-Witheford, N. (1999).Cyber-Marx: Cycles and circuits of struggle in high-technology capitalism. Urbana: University of Illinois Press. 


\section{Communication Infrastructure}

Dyson, E. (2001 July 11). Wireless Wonders. New York Times.

Editor. (2002 September 13). Boston Globe.

Eliasson, G. (1996). Investment incentives in the formerly planned economies. In Haavisto, T. The Transition to a Market Economy: Transformation and Reform in the Baltic States. Cheltenham, UK; Brookfield, Vt., US: Elgar.

Eremicheva, G. \& Solovieva, N. (1998). Entrepreneurs in contemporary political structures. In Kivinen, M. (Ed) The Kalamari Union: Middle Class in East and West. Aldershot, Hants, England; Brookfield, Vt., USA: Ashgate.

Estonia Master Report. (2000 April). Accessed November 1, 2002. http://www.esis.ee/ist2000/esis/reg/EEreg4.htm

Fjollberg, G. (2002). Knowledge and learning for sustainable society. Goteborg University, Goteborg, Sweden

Gylfason, T. (1996). Structural adjustment, efficiency and economic growth. In Haavisto, T. The Transition to a Market Economy: Transformation and Reform in the Baltic States. Cheltenham, UK; Brookfield, Vt., US: Elgar.

Hughes, T.P. (1983). Networks of power: Electrification in Western society, 1880-1930. Baltimore: Johns Hopkins University Press.

Hulten, S. \& Mollery, B.G. (1996). Estonia, Latvia and Lithuania: Balancing the demands for short term profitability and network expansion. In K.E. Schenk, J. Kruse, \& J. Muller (Eds.) Telecommunications Take-off in Transition Countries. Aldershot, UK; Brookfield, Vt., USA: Avebury.

Intriligator, M.D. (1997). The role of institutions in the transition to a market economy. In Haavisto, T. The Transition to a Market Economy: Transformation and Reform in the Baltic States. Cheltenham, UK; Brookfield, Vt., US: Elgar.

ITU (2001). Retrieved November 2, 2002 www.itu.int

Kruse, J., (1997). Institutional options for East European telecommunications policy. In K.E. Schenk, J. Kruse, \& J. Muller (Eds.) Telecommunications Take-off in Transition Countries. Aldershot, UK; Brookfield, Vt., USA: Avebury.

Lievrouw, L.A. \& Livingstone, S. (2002). The social shaping and consequences of ICT's. In Lievrouw, L.A. \& Livingstone, S. (Eds.) The Handbook of New Media. London, Thousand Oaks, New Delhi: Sage Press.

Lievrouw, L.A. (2002). In Lievrouw, L.A. \& Livingstone, S. (Eds.) The Handbook of New Media. London, Thousand Oaks, New Delhi: Sage Press.

Luna, L. (2000 November 13). Jumping Ship. Primedia.

Negroponte, N. (2002). Wifi philosophy. Massachusetts Institute of Technology.

Open Mobile Alliance. (2002). Retrieved November 2, 2002 www.openmobilealliance.org

Pelikan, P. (1996). State-owned enterprises after socialism: Why and how to privatize them rapidly. In Haavisto, T. The Transition to a Market Economy: Transformation and Reform in the Baltic States. Cheltenham, UK; Brookfield, Vt., US: Elgar.

Radosevic, S. (1997). The Baltic post-socialist enterprises and the development of organizational capabilities. In Hood, N. Kilis, R. \& Vahlne, J.E. (Eds.) Transition in the Baltic States: Micro-level Studies. New York: St. Martin's Press.

Semenova, V. (1998). On transition to the middle class: Professional strategies of young intellectuals in Russia. In Kivinen, M. (Ed) The Kalamari Union: Middle Class in East and West. Aldershot, Hants, England; Brookfield, Vt., USA: Ashgate.

Shenk, K.E., (1997). Transition: Introduction about key objectives, constraints and bottlenecks for telecommunications development. In K.E. Schenk, J. Kruse, \& J. Muller (Eds.) Telecommunications Take-off in Transition Countries. Aldershot, UK; Brookfield, Vt., USA: Avebury.

Slomczynski, K.M. (1998). Formation of class structure under conditions of radical social change: An east European experience. In Kivinen, M. (Ed) The Kalamari Union: Middle Class in East and West. Aldershot, Hants, England; Brookfield, Vt., USA: Ashgate.

Star, S. \& Bowker, G. (2001). How to infrastructure. In Lievrouw, L.A. \& Livingstone, S. (Eds.) The Handbook of New Media. London, Thousand Oaks, New Delhi: Sage Press.

Sutherland, E. (2002 June 25). Will the OMA be Productive? M-commerce Times.

Taljunaite, M. \& Cesnaviscious, A. (1997). Attitudes towards privatization: Winners and losers. In Kivinen, M. (Ed) The Kalamari Union: Middle Class in East and West. Aldershot, Hants, England; Brookfield, Vt., USA: Ashgate. 
UNDP. (2001). Creating a Development Dynamic, Final Report of the Digital opportunity Initiative. Appendix 3.3, Estonia Case Study

United States Department of Commerce. (2002). Accessed November 2, 2002 www.doc.gov

World Bank Group, Estonia. Accessed November 2, 2002 http://www.worldbank.org.ee/

World Markets Telecom

\section{Biography}

Kimberley Leahy is a doctoral student at Florida State University. She holds an MBA from St. Joseph's University in Philadelphia. Her dissertation topic will discuss the telecommunications markets of the Balkans and the challenges the Balkans have faced vis-à-vis communication technology as they position themselves to join the European Union. Kimberley is married to John Leahy, and they own a home in Tallahassee, which they share with their Pomeranian, Pom Pilot. 